Human Dignity as a Sui Generis Principle

DR STEPHEN RILEY 


\section{Human Dignity as a Sui Generis Principle}

\section{DR STEPHEN RILEY}

Abstract This paper argues that human dignity is a suigeneris status principle whose function lies in unifying our normative orders. More fully, human dignity denotes a basic status to be preserved in any institution or process; it is a principle demanding determination in different contexts; and it has its most characteristic application where the legal, moral, and political place competing obligations on individuals. The implication of this account is that we should not seek to reduce human dignity to either a legal norm or a legal principle.

\section{Introduction}

Talk of human dignity's special importance in our constitutions and in our thinking about law as a whole is widespread. But without a jurisprudential theory explaining why human dignity is more than a norm this talk will remain indeterminate and rhetorical.

My conclusion is that human dignity is a principle but one distinct from our normal characterisation of legal principles. It generates decisions, or is given determination, when our normative orders - i.e. law, morality, and politics - are in dispute. The normative and doctrinal implications of this are that some, though not all, of our common regulative uses of human dignity will become difficult to defend. The philosophical conclusion is that human dignity is not only inconsistent with prevailing theories of legal principles, but that it is sui generis in that this inconsistency arises from a distinctive function related to normative ordering as a whole. Only this characterisation satisfactorily connects our foundational ideas to at least a proportion of human dignity's existing regulative uses. 
The guiding question used to reach this conclusion is how human dignity might be said to be a 'foundation'. The ascription of foundational status to human dignity is commonly found in human rights law, constitutional law, and other legal contexts. It remains contested what this means and whether human dignity is foundational in the same way for different fields of regulation. The most general form of this question of foundations is whether and how human dignity is foundational (i.e. necessary) for certain laws and, conversely, if and how law is foundational (i.e. necessary) for human dignity. Clarification of the relationship between human dignity and law will lie partly in how we understand it as a principle within a theory of legal principles (section 5). In part it will require explaining and justifying how 'foundational' can mean 'extra-legal' (section 4). And, in part, conjoining law and human dignity requires understanding how the existing law of human dignity can and should feature in philosophical reflection (section 3). But law's own claim to be a necessary condition for human dignity must be found in isolating that part of human dignity that is necessarily related to justice. This will be the concern of the next two sections.

\section{Human Dignity as Concept}

The present paper does not survey the vast and growing literature on the concept of human dignity in ethical and legal discourse (see Daly 2012; Debes 2017; Düwell 2014). It is concerned, rather, with coherence between ethical and legal discourse. This section outlines, without fully defending, a concept of human dignity that will be later defended as the product of a more comprehensive reconstruction.

An initial distinction separates human dignity as a justice-based concept from human dignity as a virtue-based concept. Assuming that this distinction is defensible (it is challenged by Hennette-Vauchez 2011), there are good reasons to favour characterisation of human dignity in

relation to justice. Aligning human dignity with justice not only yields other-regarding (rather than self-regarding) duties but it already commits us to a certain view of practical reason within our normative orders, namely that those orders should be made to respect the basic status of 
individuals (Neal 2014, also below). Moreover, it relies neither on philosophical anthropology nor on contractarianism for its defensibility. That is, defence of a justice-centred concept of human dignity can rely exclusively on ideas and practices immanent in contemporary human rights discourse without relying on positive law, or on contractual claims, or on species-based claims (see Kateb 2011, also section 4 below).

A second distinction within a justice-based concept of human dignity is whether it must be articulated as a value or as a status concept. The first would relate to axiology and requires an account of what we should value and how, particularly how the value of agents and their ends should feature in our deliberation. The second would relate to principles of rights-conferral, autonomy, and respect. The reason why we should favour the second is found in the ambiguous relationship between human dignity and Kantianism. If ethical and legal discussion have an agreed meeting-point it is that human dignity's significance lies in demand to "[a]ct in such a way that you always treat humanity, whether in your own person or in the person of any other, never simply as a means, but always at the same time as an end." (1948, 91 emphasis removed) This relates to certain foundational commitments established by Kant in his Groundwork (1948), but this has been adopted in a much simpler form as the basis of various regulations in law. That is, lawmakers and judges have taken this idea to mean that we should directly prohibit the objectification or instrumentalisation of individuals (see Enders 2018). For Kant 'dignity' was foundational in expressing the possibility of unconditional ends, i.e. categorical imperatives (Kant 1948, 96-97). But it was not intended to be translated directly into legal prohibition of treating others as mere means. It was intended as a test for individuals to apply to their maxims for action. We, and the courts, treat this prohibition as foundational in a way that Kant would not. Consequently, what we might call the 'Kantianism of the Groundwork' supports central a relationship with justice, rather than virtue. But Kantianism does retain, first, a close relationship between human dignity and duties rather than rights. This relationship keeps virtue ideas in play, and inclines us towards a discourse of special intrinsic value which has less clear connection with justice. Second, the 
Kantianism of the Groundwork is incomplete as a ground for generating legal norms. Our special value is not defeasible. This in turn means that legal attempts to positivise human dignity have centred on grosser forms of objectification (see in particular the jurisprudence of Günter Dürig, discussed in Enders 2018). To be concerned with human status is, in contrast, to be concerned with structural and institutional defences of basic respect, autonomy, and self-determination. It requires a theory of entitlement not ontology, and it should produce principles for action, not values to be realised. In focussing on justice and status we are not, then, concerned with the ontology of humanity vis-à-vis anything else and nor are we concerned with a special value that individuals should attribute to themselves. This reflects Kant's own practical concern with dignity in the 'Doctrine of Right' where dignity relates both to the means of maintaining social status and relates to his idea of 'innate right' as the bridge between basic entitlements and positive law (Kant 1996, 30-31). Kant used a status concept of dignity when he was concerned with generating principles for positive law, as should we (see similarly, Riley 2017; Waldron 2012, 202; Weinrib 2016).

This appeal to status is also important because it entails that our concern with the maintenance of human dignity lies in practices, not in inherent value or philosophical anthropology. By focussing on status rather than value we are denying the existence of a paradox whereby human dignity is an inherent possession but also susceptible to diminution or destruction. We should, through a discourse of status, think in terms of principles defending the universality of our basic entitlements.

Finally, a certain distance from familiar Kantian discourses of value and end-in-themselves should also signal that there can be no simple deduction of legal commands or prohibitions from human dignity. Human dignity has gained currency in legal and political discourse as symbolic or expressive of a fundamental reorientation in law and in law's self-understanding: a turn towards the individual. Prohibition alone therefore fails to acknowledge the scope and depth of human dignity's normative and systemic implications. Dignitarian law must also be a law of positive 
entitlements. However, if contemporary discourses of human dignity cannot be understood without reference to law (be it international, human rights, or constitutional law) human dignity stubbornly refuses to be reduced to law. This is evidenced, amongst other things, by our ongoing struggles to understand what it means to have human dignity as the foundation of a body of laws or of a constitution (Barak 2015). Understanding this non-reducibility is essential to understanding human dignity.

\section{Human Dignity as Foundation}

If an argument can be made, via a certain form of Kantianism, for human dignity's conceptual core to be associated with justice and with status, this still requires clearer connection with and justification for our ascription of its being 'foundational'. We need know if and how it is foundational. We need to know if and how it must be concretised (made directly normative) or realised (supported indirectly by institutional arrangements) in law. And we need to know what is left over of human dignity when its legal functions have been fulfilled. Law may be a necessary but not sufficient condition for human dignity even if we make justice intrinsic to the concept.

A number of specific foundational discourses arise from human dignity. Some of these discourses associate human dignity with (or treat it as a synecdoche for) social or political changes. This would be, for example, because human dignity reflects certain tectonic shifts in human practices and thinking at a sociological (Waldron 2007; Cotterrell 2011) or psychological (Hunt 2004) level. The foundational function of human dignity in this sense ranges from the broadly expressive (human dignity expresses a turn towards the individual at these sociological or psychological levels) to the specific meaning of social dignities (statuses) and how these have changed.

Such foundational 'structures' broadly denote social or ideological patterns that have given rise to certain distinctive social or ideological practices. We should distinguish these foundational structures from a different kind of normative foundation, namely as a source of validity (human 
dignity as a norm of one kind or another) or as a privileged source of critique (human dignity as a postulate or ideal).

In a first pairing of normative foundational ideas, we could contrast human dignity as a regulative idea (an ideal to be approached but never reached) with human dignity as immanent idea in law (always present in well-functioning systems). Jeremy Waldron's work combines elements of both. Human dignity's immanence is immanence in law's participatory practices: good law maximises participatory practices regardless of their direct utility because of their manifestation of respect for individuals $(2011 ; 2012 \mathrm{a})$. In contrast, the 'regulative idea' conception of human dignity is close to but not quite synonymous with the rule of law $(2008,60)$. Waldron's writings on torture involve a vision of progressively more individual-orientated law expressed through unconditional prohibitions inseparable from the rule of law (2005). Law is required to acknowledge individualprotecting principles because law approximates to an archetype drawing it towards a more individual-protecting form.

A second distinct pair of foundational, normative, ideas are important, namely as a 'basic norm' contrasted with what we can call a 'background norm'. As a basic norm we could (departing immediately from the Kelsenian vision of a Grundnorm (Kelsen 1967)) treat human dignity as a substantive postulate assumed by a legal system (see Neal 2014). This would treat human dignity as a basic obligation implicit in all, and explicit in some, legal interactions. We could, in contrast, assume that human dignity is not a norm conferring validity on a system of norms but something that lies dormant in a system as a commitment controlling public power and relevant only to prevent egregious misuse of it (Weinrib 2016). This 'background' conception of human dignity and law, associated with the expressive function of human dignity to signal a society's rejection of its own unjust past, would insist that invocation of human dignity has real significance only in those circumstances where the rule of law is under threat or has been suspended. Even if legal justice can be suspended by a state, human dignity cannot be. This idea is considerably narrower than the broad associations between legal systems and human dignity we have encountered so far. 
It is, arguably, too narrow in suggesting that human dignity only has relevance in extremis in constitutional crisis. It does, however, indicate a structural position for human dignity - conjoining the political, moral, and legal - that offers more functional precision than the dissolution of human dignity into an immanent or regulative idea. If this background function has attractions - not least its being of constitutional importance but also having direct application in constitutional crisis - it remains uncertain how it should be operationalised. Whether it speaks to institutional design or to judicial powers, and whether this offers a satisfactory bridge between human dignity as a foundation and human dignity as a norm or rule.

Indeed, each of the foregoing discourses of foundations require a systematic understanding human dignity's place in practical reason, if not its precise normative implications. We need to know how the constitutive (or principled) yields the regulative (or directly normative). And we should distinguish whether the concretising (positivising) of human dignity into certain legal norms is the same as properly realising (sustaining the necessary conditions of) human dignity in law.

\section{Human Dignity as Regulative}

What if anything does the existing positive law of human dignity contribute to our understanding of human dignity as a foundation? We can see immediately why this question might be both important and problematic. If a foundational role for human dignity were identified without reference to the positive law of human dignity it would be difficult to know how the constitutive and regulative were meant to coexist or the one be derived from the other. Conversely, finding a way of rendering our regulations coherent - creating a theory of the positive law of human dignity - might fail to 'link-up' with foundational discourses constructed in isolation from those regulations. The regulations properly associated with human dignity remain ambiguous because the 'proper' constitutive (or foundational) sense of human dignity itself remains ambiguous. They cannot be identified in any uncontroversial way because human dignity's authentic or focal meaning is contested (see Rodriguez 2015, but also Düwell 2012). These 
problems in turn underlie a substantive and practical problem. The law of human dignity appears to be a principled and useful element of legal systems. But the law of human dignity cannot be conceptually unified. Such unification is not the function of legal institutions. And any coherence or consistency in legal usage would still leave open the question of whether this is consistent with its extra-legal meaning.

These general problems are manifest in three partially distinct problems found in the positive law of human dignity. Imprecision in the sense that human dignity rarely emerges from legal use with enhanced descriptive or normative clarity such as to produce a precise body of jurisprudence. ${ }^{1}$ Redundancy in the inability of human dignity to provide a distinctive contribution to our regulations, one that is not substitutable for other normative notions like respect or equality. ${ }^{2}$ Above all, incoherence in human dignity's failure to provide a coherent connection between what we consider constitutive, and what we consider regulative, in our discourse. ${ }^{3}$ We want to talk of human dignity as foundational or the bedrock of legal systems (a 'constitutional value', the 'principled core of human rights') but this is not to prove its interpretative or adjudicative necessity in the application of law. The result of this is a kind of collapse of the constitutive. We can make foundational claims about human dignity, but we confront a body of regulations that apparently cannot be brought within any general rule or principle.

The reason for this fracturing of human dignity in law is because of the absence of a 'community of interpretation' in a common jurisdiction (McCrudden 2008). But it is equally important that positive law cannot make sense of the persistent foundational discourse of human

\footnotetext{
${ }^{1}$ Does everything that has happened under the auspices of the UN (and related international organs) over the last 70 years count as a contribution to human dignity? Judicial and scholarly discussion of human dignity and human rights norms in international fora sometimes seems to suggest so (e.g. South-West Africa Cases [1966]; ICISS Report (2001); Teitel 2011). But this is to erase all descriptive or normative precision that human dignity might have. 2 Along with respect and equality, in bioethical contexts the usual connections between human dignity, autonomy, and self-determination are substituted for certain ideas closer to human sanctity or capacity to consent.

${ }^{3}$ For example, how should 'human dignity' be used in US constitutional discussions? It has no presence in the fabric of the constitution but is a frequent feature of Eighth Amendment jurisprudence (see Daly 2012). Does this mean that the US has incorporated aspects of international human rights discourse into its constitutional jurisprudence or does it simply mean that human dignity has its clearest juridical function in the context of degradation? If domestic systems 'filter' or reduce the significance of human dignity to a prohibitive function does this mean that human dignity only has constitutive significance at the international level?
} 
dignity as an extra-legal foundation (see Kirste 2009). In fact, the phrase 'extra-legal' reveals a central knot of problems. This suggests both that it has distinctive moral force and that it is alien notion imported into legal systems. It suggests that it is irreducibly moral, and this irreducibility is a check on legal power because of a capacity to resist conditioning or limiting by legal reasoning and by legal institutions. Such suggestions yield further problems. Does 'extra-legal' therefore mean having no direct regulatory manifestations in our law? In other words, could we have commitment to human dignity in a system and yet have no need to ever invoke it directly? If so, are all of our existing positive regulations using 'human dignity' ultimately senseless?

It is also important to note that the precise meaning of 'extra-legal' must take its meaning against a general jurisprudence. The very meaning of 'legal' and therefore what stands 'outside' law cannot be theoretically neutral. Accordingly, we have to ask how and in what sense must 'foundation' be understood as extra-legal and whether this requires, permits, or precludes having directly enforceable normative correlates in law. These in turn will generate a deeper set of questions about our methodology of reconstructing concepts using legal norms and the extent to which the notion of 'principle' can satisfactorily bridge this putative separation between legal and extra-legal and between constitutive and regulative.

\section{Reconstruction of Human Dignity}

I will argue that we will find the focal - coherent, morally and legally defensible - concept of human dignity through an analysis of human rights taken in a broad sense. This is not to say that explicit human rights law or adjudication has, through application of human dignity, revealed a coherent concept. Rather, a general and coherent understanding of human rights law as such will reveal the kinds of normative materials necessary for a coherent idea of human dignity. Even though this will vindicate a view of human dignity as 'founding' human rights laws it is not circular. It is the underlying structure of human rights law that I take to be instructive, not specific human rights. 
We should begin with the more explicit relationships between this field of law and human dignity. Human dignity fulfils a number of possible foundational roles in human rights discourse (see Waldron 2013). It explicitly founds human rights regulations, it guides the interpretation of the law, and it seems distinct from, indeed immune to, the standard canons of legal interpretation (Dupré 2016, 194). And it 'exists' in a distinctive way, not as norm to which a body of precedent attaches but an extra-legal perspective giving direction and principled unity to the law (see Pretty $v$ UK [2002] para. 65). Human dignity has assisted in producing a stable interpretative position regarding the adjudication and evolution of human rights as well as being given substantive form in terms of a connection with basic interests, the limits of the state, and with human autonomy (McCrudden 2008, 679).

We still, however, face a choice between whether human dignity is to be taken principally as a substantive commitment containing direct normative implications or whether human dignity serves a heuristic function bringing certain interpretative assumptions to bear in adjudication but has no independent normative implications (Dupré 2016, 16f). How could we decide whether its basic, or focal, function lies in interpretation or prohibition? The jurisprudence of the European Convention on Human Rights clearly illustrates human dignity as making a dual contribution to human rights law: eliciting creative interpretation of the laws and grounding a specific prohibition on degradation (Costa 2013). To get beyond that bivalence we have to think more generally about the structure of human rights law and three overlapping levels of description.

First, human status is the normative core of human rights law. At their centre human rights assert the status of the individual through the attribution of rights to the individual qua human not qua citizen and as a sovereign within a sphere of basic practices and entitlements (Feinberg 1970). At the level of substance, status means ascribing a range of human rights - economic and social as well as civil and political rights - that are basic entitlements defending this sovereignty. And at the level of philosophical justification, status sits between a theory of human nature and a theory of basic entitlements. We are concerned with the entitlements arising from the unconditional 
status ascribed to humans aside from their contingent statuses and contingent entitlements. Such status is, then, irreducibly cosmopolitan (see below).

Second, human rights law is, more than any other, a principled body of laws insofar as human rights have a formal unity in being rights that accrue to humans as such. This is formal but not empty because it prevents appeal to the will of the state or law-maker to authorise the laws or to be the locus of their interpretation. The principle is not, then, merely limitation of state power, but a particular normative and discursive principle about the shape of the relationship between state and individuals (and indeed horizontally between individuals). Status gives us the principled expression of the fundamental structural entitlements of individuals. The human rights derived from basic status are qualified only under explicit qualifying criteria concerned with collective goods that are themselves demanded by practical reason not justified by the will of the state alone (Finnis 2011, 218-226).

Third, human rights through their substance, through their careful qualification, and through their institutional independence, have an interstitial scope. They have an impact on the legal and the political and can be expressed in the language of law, morality or politics. Moreover, they have special application in the meeting point of these normative orders. Human rights are interstitial in not respecting divisions between fields of law and indeed having a role in drawing them together. It is human dignity that, in this its most distinctive 'heuristic' role, allows human rights law to appeal quite directly to morality or politics, be it in the form of appeal to the moral basis of the rights or in the form of a court's entitlement to determine the proper 'margin of appreciation' in the realisation of rights.

This then forms the basis of a reconstruction. It picks and chooses amongst salient aspects of our human rights regime. Certainly those choices in turn are informed by conceptual commitments about human dignity per se that are contestable (section 1). The concomitant gain is purchase on both a key aspect of the (moral) concept of human dignity and on part of the (positive, practical) functions of human dignity that are found in law generally and human rights specifically. 
The result, I will go on to argue, makes sense of the problematic but inescapable extra-legal element in the functioning of human dignity. The claim is best thought of as arising from attempts to capture human dignity's interstitial scope.

This also answers, at least in outline, how we should understand law as a necessary condition for human dignity but not a sufficient condition. While the rule of law - good ordering between our normative orders - is indeed a necessary condition of human dignity, we can also begin to identify what remains outstanding to be sufficient for human dignity. These necessary conditions will be, in part, human rights as the bridge between the principle of human dignity and our legal institutions. They will also, in part, be those cosmopolitan concerns that characterise international human rights. That is, there is no sense in talking about the isolation of human dignity to one legal system. And there is no potential to reduce human rights to the "basic constitutional rights' provided by particular states. Human rights are cosmopolitan rights even if human rights are structured in such a way as to respect subsidiarity (Carozza 2011).

Before we turn to those questions of general jurisprudence, a reconstruction using human rights gives rise to at least two more specific objectives and questions. First, whether there is such unity (or 'indivisibility') in human rights as this account suggests. And, second, whether all human rights norms are 'dignitarian' norms and what this means. With regard to the first, given that the class of human rights is highly diverse and contested any derivation of a basic principled core seems to be question-begging. In contrast, I think we should understand the idea of the 'indivisibility of human rights' as a commitment to human rights as a distinct class of rights (Nickel 2008). Indivisibility warns us against those cherry-picking approaches where human rights laws are reduced or rationalised on the basis of their reflecting long-standing constitutional laws. More generally, I have assumed that the formal conception of human rights as rights accruing to humans must assist in interpreting positive law such that the content and application of human rights could not be confined to 'civil and political' rights granted by states. No defensible reconstruction of human rights can be confined to civil rights to the exclusion of other international rights; human 
rights have a structural integrity that militates against more pragmatic or purely political conceptions of human rights.

With regard to the second claim that all violations of human rights now appear to be violations of human dignity, or that violation of one is always violation of the other, the charge would be that the discourse of human dignity now becomes over-expansive and that all and any violations of human rights are uniformly impermissible and blameworthy (noted by Mahlmann 2013). Note this is only implausible if we assume that 'violation of human dignity' must be understood as violation of core or basic rights striking at the heart of the individual life, liberty or basic humanity. We have not presumed this conclusion and nor should this be taken to be a viable assumption with regard to the nature of human dignity. Recalling the ambiguity of human dignity in the context of human rights between heuristic and substantive functions, we should certainly concede that human dignity has given rise to a broad interpretative body of thought regarding the nature, defensibility, and adjudication of human rights and also a quite specific and substantive commitment regarding the wrongfulness of dehumanisation and related practices (for comparison see Dupré 2016, 16-18). The reduction of its substance and force to prohibiting degradation is inadequate however symbolically important this might be (and however useful the language of '(in)dignity' is within the phenomenology of degradation). Human dignity is a principle that generates, justifies the content of, and justifies the qualifications that legitimately limit human rights law.

\section{General Jurisprudence}

We have translated the 'foundational' into the principled, translated the 'extra-legal' into the interstitial, and taken the normative core of human rights and of human dignity to be the status of the individual. Does this resolve problems around the analysis of human dignity as a component of law or a foundation of law? In particular does it clarify how we identify dignitarian entitlements in legislation and adjudication? 
Three areas of clarification are important. The nature of human dignity as a principle. Its position within a theory of practical reason. And an evaluation of the (jurisprudential and conceptual) significance of human dignity as a 'moral' concept. Each of these, in different ways, support the classification of human dignity as a sui generis principle.

\subsection{Principles and Law}

We need to explore the idea that human dignity is a self-standing principle able to generate determinate decisions. We should not seek to reduce human dignity a legal principle. It can nevertheless function as a legal principle and produce norms in legal contexts. It will be crucial to amplify this distinction.

Contemporary jurisprudence aligns principles either with our general legal norms or gives legal principles only a limited set of functional applications in law. Depending upon the theorist, legal principles must be susceptible of being weighed (Dworkin 1986) or be the kind of norm or value we can optimise (Alexy 2009). We could conclude, therefore, that any attempt to describe the constitutive aspect of human dignity as a principle cannot be expressed in terms of a legal principle because human dignity cannot be intelligibly weighed or optimised, at least to the extent that it concerns basic human status. In contrast, I deny that we must define principles as having univocal functions.

Principles are obligations giving rise to reasons for action and to judgments (Cohen 2003). Under that description of principles we should attend closely to Mary Neal's statement that "dignity itself is never truly weighed against other values: no outcome can be both dignity-violating and legally acceptable" $(2014,36)$. The fact that we seek to 'get the dignity picture right' rather than 'apply' human dignity (ibid., 36) means that human dignity is not legally conclusory in any simple way. It is a wholly distinctive interpretative and judgement-permitting phenomenon, immune from the usual interpretive canons. It is not always conclusory, but nor is it defeasible. 
To, in turn, treat such indefeasibility as amounting to an 'absolute' principle is equally problematic. This makes its adjudicative function peremptory in such a way as to challenge the rule of law itself: a principle that simply sweeps aside other norms is inconsistent with normative stability or precision. Teifke and Alexy soften this problem by making it internally complex as a principle. For Teifke "there is no absolute principle [and no] rule of human dignity that is independent of the principle of human dignity and absolute. Rather human dignity is simply a principle that is limitable but with a predominant abstract weight" $(2010,103)$. This seems descriptively correct and legally coherent. Nevertheless, such abstract weight presumes that we know where and why human dignity is to be employed and that there are circumstances when it could be defeated or outweighed. It is difficult to specify a priori where such circumstances would hold, and in particular whether human dignity could only be defeated by human dignity insofar as a dignitarian (self-regarding) duty might outweigh another dignitarian (other-regarding) duty. ${ }^{4}$

Robert Alexy insists that human dignity is (at least in the German context) bifurcated into a rule and principle and properly operationalised in the class of judgments related to liberty; human dignity is not defined by liberty but rather "[n]egative liberty is a necessary but not a sufficient condition of human dignity" $(2009,232)$. He therefore, rightly, resists attributing adjudicative primacy to a human dignity rule given that the content of any human dignity rule will be overdetermined by jurisprudential history within a legal system. He instead points to a number of principled applications enhancing negative liberty. But the bifurcation of human dignity into rule and principle is nonetheless problematic. Even in its principled form it seems to be determined by its position and function within a specific constitution. For example, in Germany the rule of human dignity prevents the reduction of the individual to an 'object' while the principle of human dignity includes providing conditions "which protect the innermost aspect of human beings, and those which grant to the individual a prima facie right to self-representation before fellow human

\footnotetext{
${ }^{4}$ For example (and notoriously) in Wackenheim [2002] a (dignitarian) protection against harming one's own dignity outweighed the (dignitarian) human right to work.
} 
beings" (2009, 235). Under this division, human dignity's proper use in legal judgment remains difficult to determine a priori because "the principle of human dignity has to be made more precise by a bundle of sub-principles, which [...] include numerous substantive principles which in the balancing process appear alongside negative liberty and can determine its weight" (2009, 236). Given the opacity of this further bundle of principles, it is hard to see how human dignity can be anything other than a substantive prohibition on degradation and a heuristic explicating and expanding negative liberty. In other words, this account of the German Constitutional conception of human dignity grants it an equivocal position not unlike that found in the jurisprudence of the European Convention on Human Rights.

This also recalls certain aspects of the problematic relationship between the constitutive and regulative. On the one hand we should not expect our foundation to be so extra-legal that it has no stable application in legal reasoning. On the other we should not expect our existing explicit manifestations of human dignity in law to reveal a unified principle applicable across legal systems. This latter drive for direct discovery of human dignity in law is methodologically wrong-headed insofar as human dignity is a principle requiring determination in law, i.e. concretisation into rules or particular judgments (Finnis 2011, 284f). In other words (and methodologically) we should start our thinking with the principle and attempt to hold on to its normative core rather than posit a range of principles founded on bundles of possible meanings. And (at a doctrinal and substantive level) it is the sui generis implication of human dignity, qua principle, that it cannot be authoritatively or finally defined by any one legal system. In other words, there cannot be 'system-specific human dignity', either as a principle or as a rule.

\subsection{Practical Reason and Law}

On the foregoing assumptions it would be incoherent to make human dignity the foundation of law (alone), or politics (alone), or morality (alone). These claims could only be made intelligible by collapsing human dignity into the ideas of justice, virtue, or obligation at the cost of 
human dignity losing its meaning altogether. What connects its legal functions with more expansive foundational claims is the governance of our systems - of all our normative practices in ways that are orientated towards individuals. Human dignity is distinctively interstitial in our normative discourse and normative practices. It is applicable where sources of obligation meet.

How does this reconstruction of human dignity relate to our practices? And what would be paradigm examples of the use of human dignity as an interstitial principle? This reconstruction certainly correlates with what we might treat as the 'spirit' of human rights law. That is, protection of the status or value of the individual irrespective of the counter-veiling normative demands that can be made by legal, moral and political systems. And it reflects the structural relationship between human rights and other fields of legal practice. That is, human rights law is used to centralise the individual in politico-legal discussion in a way which accommodates the qualifications necessary to respect the differences between our normative orders and which accommodates dynamism in our social practices.

Accordingly we should not only expect to see human dignity at work in human rights law or in situations of constitutional crisis but also in any hard cases where the moral, legal and political each make apparently incommensurable claims to authority. In judgment it will be assumed that, as far as possible, we should free individuals from conflicting responsibilities arising from these normative orders (Harel 2014, 107f). Moreover, we should rightly see human dignity invoked in normatively complex phenomena like civil disobedience and humanitarian intervention (Dworkin 2013). Invocation of human dignity is, in these kinds of cases, not a sign of normative desperation but rather evidence that we are compelled to find legal answers consistent with human status in circumstances where law, morality, and politics yield different obligations.

This vindicates, then, a certain kind of a 'background norm' reading of human dignity that would allow it to articulate egregious failures of a state. Not because human dignity can be used to signal and then oppose descent into barbarity (Habermas 2010; Weinrib 2016). Rather, because provides a positive idea of what it is to preserve status within a stable democracy or Rechtsstaat. 
This also means vindication of Waldron's apparently heterogeneous dignitarian commitments. Waldron's dignitarian functions are united by a concern with legal ideals, structural ideals concerning the interaction of the legal, political and moral both at the level of lived participation in law or at the level of good legislative practices. We should, therefore, give particular force to his ideas of 'presence' and 'participation' in law, not as part of a phenomenology of respect but rather as valorising certain political aspects of law and legal aspects of the political. We should also stress that a grounding in status is the best route to conceptualise human dignity in our practices. As an anthropological, not an axiological, principle we are defending status practices not special value.

What are the implications of such an account? Our regulative uses would therefore be rationalised on the basis of varying degrees of connection with this interstitial function. We can, for instance, agree that there are points of contact between 'human dignity proper' (an interstitial principle relating to status) and 'dignity' in biolaw or healthcare law. To the extent that individual status is at issue, the connection is intelligible. But a focal deployment of the concept would require a judgment on status such that the moral, legal and political are harmonised to the benefit of the individual. In healthcare and bioethical contexts, by contrast, there is often a much cruder deployment of human dignity allowing the moral to simply trump the legal. The defensibility of other regulative uses depend upon whether they can show a direct relationship with human dignity as an interstitial principle or are determinations of the principle. Many (if not all) of our legal discourses of 'degradation' are - defensibly - discourses of human dignity in that sense because they represent the political violating both legal and moral obligations. ${ }^{5}$

\footnotetext{
${ }^{5}$ For this reason the human rights law of degradation focuses on the particular wrong of agents of the state - political actors - degrading citizens. Degradation for the purposes of human rights law must have this (broadly) political element. This element, related to rectifying the illegitimate use of political authority, is still sometimes confused with a different question: whether a dignitarian wrong is a wrong that strikes at an individual's basic buman status or that strikes at their social status (their 'social dignity'). For the purposes of human rights law, it is both and neither: it is distinctive misuse of political authority. For a good analysis see Webster 2016.
} 
Nonetheless, the paradigmatic, principled, use of human dignity in law is something we are likely to see only where normative orders are in dispute. For example, where executive power and executive exceptionalism are challenged by appeal to the rule of law (Weinrib 2016). Or where legislative power is challenged by judicial review (Harel 2014). Determination of human dignity will, then, typically be an attempt to appeal through human dignity to the primacy of a legal, political or moral obligation as that which properly respects basic human status in this context. As a consequence, even though we have relied upon human rights law to produce this reconstruction, we should not be looking for our paradigmatic expression of human dignity in the preambles of international human rights treaties. Rather, we find human dignity in those interstitial problems where the solution to clashes of law, morality and politics can only be solved, in a principled way, by making our systems fit human status and not the other way around.

\subsection{Moral Concepts and Law}

This investigation reflects a desire to consider human dignity from a 'legal point of view'. This of course contains many of the ambiguities that have already been in play. 'Law' itself being either a practice or the product of practices. A 'point of view' being from either within and without legal institutions. We, if nothing else, need consider how a general theory of law and a sui generis principle interact. We can, therefore, give particular attention to inclusive legal positivism as an attempt to deny or denature that sui generis status.

An 'inclusive' positivist position might well stress how the 'moral' is included in law as a standard; moral claims, especially the moral rights of the individual, can be identified as valid by a rule of recognition. The conception of human dignity that this supports - a legal side constraint on mistreatment - reflects a broadly constitutive function (protecting autonomy or inviolability) without disrupting the normative priority of the social sources of law in legal reasoning or the general normative primacy of the legal over the moral. Various contemporary writers import variations on this model into their thinking. Scott Shapiro, for instance, articulates human dignity 
as a kind of side constraint. He argues that German constitutional provisions giving positive legal force to human dignity

seem to condition legal validity on moral considerations. Thus, according to this interpretation, provisions that violate human dignity are not legally valid in the German legal system. Inclusive positivists can explain how such phenomena are possible: because officials in these systems accept that cruelty and dignity are relevant to legal reasoning, these moral considerations are ultimately backed by social fact and hence can determine the content of the law. $(2011,270)$

There are good reasons to be suspicious of this rapprochement between the legal and 'moral'. One is simply that this offers no solutions to the normative, adjudicative, and constitutive problems our review of regulative uses of human dignity revealed. Inclusive positivism aims to sustain human dignity's broadly moral force while leaving the concept to be operationalised and worked pure through legal practices. But no such working pure will be forthcoming given the 'collapse of the constitutive' already described, i.e. its reduction to a standard of degradation, and a rejection of practical constitutional significance. Shapiro's specific position - that we should maintain a special place for human dignity in legal reasoning because of its contribution to our understanding and prohibiting cruelty - abandons the possibility of human dignity having either a function as principle dispositive of legal disputes or a function as determinative of a system's conception of the rule of law. Regulatory usefulness comes at the price of constitutive incoherence. To be sure, constitutional interpreters are required to prohibit cruelty where they find it. But we are no clearer about what human dignity adds to that task or indeed how that task should be through to permeate the whole of the constitution.

Alexy, as we have seen, uses human dignity to explicate the German Constitution's general right to liberty.

[T] he principle of human dignity is capable both of supporting and explicating the principle of negative liberty. This is possible because the principle of human dignity 
has to be made more precise by a bundle of sub-principles [which] in the balancing process appear alongside negative liberty and can determine its weight. (2009, 236) These sub-principles are, Alexy concedes, contested conceptions around an opaque core concept (ibid. 233). Thus a basic normative and constitutive connection with liberty is posited. But in practice human dignity is operationalised in various other 'bundles' of entitlements that are only connected by webs of family resemblance resulting in a familiar fracturing of human dignity into various conceptions. This makes sense of the common regulative connection between human dignity, autonomy, and liberty. But it falls short of treating it as a sui generis principle which, after all, is what human dignity's primary position in a constitution suggests.

The inclusive positivist offers a tempting route to include the idea of human dignity as 'moral' idea, where the inverted commas indicated ersatz moral status but reduction to a legal norm. The procedural naturalist, in contrast, appears much closer to the mark in insisting that we have no need of explicit norms ('moral' or otherwise) to include sui generis principles in our thinking: they are already part of our conception of law when we talk about the rule of law or the inner morality of law (Fuller 1969). The unity of our normative orders, and the significance of moral ideas for understanding what is constitutive of law, are, ultimately, however a theme from classical natural law (Finnis 2011).

\section{Conclusion}

In legal terms human dignity is not what it is, or at least not what conventional legal assumptions would have it be. It is distinct from law, but must have a place in legal thinking. It is a principle in law, but not a legal principle. It requires the rule of law, but its meaning is not exhausted by the rule of law.

Because of its conceptual idiosyncrasy human dignity has been subject to philosophical and legal critique as imprecise and empty. We have seen some of the reasons for human dignity's alleged imprecision namely because it can be taken to be a principle or a heterogeneous body of 
norms. But note that 'emptiness' fails to be good grounds of critique because, even where we find a placeholder marking the absence of agreement, the placeholder itself must indicate the shape of the possible agreement. This agreement on the centrality of human dignity, this unifying principle of the post-world order, takes the form of a (simultaneously moral, political, and legal) commitment to the status of individuals. Reconstructing this idea - filling-in the placeholder means accepting a unique principle that has its practical function between the legal, political, and moral rather than subsuming one under another. More completely, human dignity is a sui generis status principle whose paradigmatic function is in interstitial contexts.

Leicester Law School University Road Leicester LE1 7 RH 


\section{References}

Alexy, R. 2009. A Theory of Constitutional Rights. Oxford: Oxford University Press.

Barak, A. 2015. Human Dignity: The Constitutional Value and the Constitutional Right. Cambridge: Cambridge University Press.

Brownsword, R. 2014. Chapter 1: Human Dignity from a Legal Perspective. In The Cambridge Handbook of Human Dignity: Interdisciplinary Perspectives. Eds. M. Düwell et al, 1-22. Cambridge: Cambridge University Press.

Carozza, P. 2011. Human Dignity in Constitutional Adjudication. In Research Handbook in Comparative Constitutional Law. Eds. Tom Ginsburg and Rosalind Dixon, 11-17. Surrey: Edward Elgar.

Cohen, G. A. 2003. Facts and Principles. Philosophy \& Public Affairs 31: 211-45.

Costa, J-P. 2013. Human Dignity in the Jurisprudence of the European Court of Human Rights. In Understanding Human Dignity. Ed. C. McCrudden, 393-402. Oxford, Oxford University Press.

Cotterrell, R. 2011. Justice, Dignity, Torture, Headscarves: Can Durkheim's Sociology Clarify Legal Values? Social \& Legal Studies 20: 3-20.

Daly, E. 2012. Dignity Rights: Courts, Constitutions, and the Worth of the Human Person. Philadelphia: University of Pennsylvania Press.

Debes, R. ed. 2017. Dignity: A History. Oxford: Oxford University Press.

Dupré, C. 2016. The Age of Dignity: Human Rights and Constitutionalism in Europe. Oxford: Bloomsbury Publishing. 
Düwell, M. 2010. Chapter 15: Human Dignity and Human Rights. In Humiliation, Degradation, Dehumanization: Human Dignity Violated. Vol. 24. Eds. Kaufmann, Paulus, et al., 215-30. Springer Science \& Business Media.

Düwell M. et al eds. 2014. The Cambridge Handbook of Human Dignity: Interdisciplinary Perspectives. Cambridge: Cambridge University Press.

Dworkin, R. 1986. Law's Empire. Harvard: Harvard University Press.

Dworkin, R. 2013. A New Philosophy for International Law. Philosophy \& Public Affairs 41: $2-30$.

Enders, C. 2018. Human Dignity in Germany. In Handbook of Human Dignity in Europe. Eds. Becchi P., Mathis K., 1-39. Cham: Springer.

Feinberg, J. 1970. The Nature and Value of Rights. Journal of Value Inquiry 4: 243-60.

Finnis, J. 2011. Natural Law and Natural Rights. Oxford: Oxford University Press.

Fuller, L.L. 1969. The Morality of Law. New Haven: Yale University Press.

Habermas, J. 2010. The Concept of Human Dignity and the Realistic Utopia of Human Rights. Metaphilosophy 41: 464-80.

Harel, A. 2014. Why Law Matters. Oxford: Oxford University Press.

Hennette-Vauchez, S. 2011. A Human Dignitas? Remnants of the Ancient Legal Concept in Contemporary Dignity Jurisprudence. International Journal of Constitutional Law 9: 32-57.

Hunt, L. 2004. The 18th-Century Body and the Origins of Human Rights. Diogenes 203: $41-56$. 
ICISS (2001) The Responsibility to Protect: Report of the International Commission on Intervention and State Sovereignty. Available at http://responsibilitytoprotect.org/ICISS\%20Report.pdf.

Kant, I. 1948. The Moral Law: Kant's Groundwork of the Metaphysic of Morals. London: Hutchinson University Library.

---- 1996. The Metaphysics of Morals. Cambridge, Cambridge University Press.

Kateb, G. 2011. Human Dignity. Harvard: Harvard University Press.

Kelsen, H. 1967. Pure Theory of Law. Berkeley: University of California Press.

Kirste, S. 2009. A Legal Concept of Dignity as a Foundation of Law. In Human Dignity as a Foundation of Law. Eds. Brügger, W. and Kirste, S., 63-82. Germany: Franz Steiner, Verlag.

Mahlmann, M. 2013. The Good Sense of Dignity: Six Antidotes to Dignity Fatigue in Ethics and Law. In Understanding Human Dignity. Ed. C. McCrudden, 593-614. British Academy.

McCrudden, C. 2008. Human Dignity and Judicial Interpretation of Human Rights.

European Journal of international Law 19: 655-724.

Neal, M. 2012. Dignity, Law and Language-Games. International Journal for the Semiotics of Law 25: 107-122.

Neal, M. 2014. Respect for Human Dignity as 'Substantive Basic Norm'. International Journal of Law in Context 10: 26-46.

Nickel, J. W. 2008. Rethinking Indivisibility: Towards a Theory of Supporting Relations between Human Rights. Human Rights Quarterly 30: 984-1001.

Pretty v UK [2002] Pretty v United Kingdom, Application no. 2346/02, Council of Europe: European Court of Human Rights, 29 April 2002. 
Riley, S. 2017. Human Dignity and Law: Legal and Philosophical Investigations. London: Routledge.

Ripstein, A. 2009. Force and Freedom: Kant's Legal and Political Philosophy. Cambridge: Cambridge University Press.

Rodriguez, P-A. 2015. Human Dignity as an Essentially Contested Concept. Cambridge Review of International Affairs 28: 743-756.

South West Africa Cases [1966]. South-West Africa Cases (Ethiopia v. South Africa; Liberia v. South Africa); Second Phase, International Court of Justice (ICJ), 18 July 1966.

Shapiro, S. 2011. Legality. Harvard: Harvard University Press.

Teifke, N. 2010. Human Dignity as an “Absolute Principle”? Archiv für rechts-und sozialphilosophie, ARSP. Beiheft 119: 93-103.

Teitel, R. G. 2011. Humanity's Law. Oxford: Oxford University Press.

Wackenheim [2002] Manuel Wackenheim v France, Communication No 854/1999, U.N. Doc. $\mathrm{CCPR} / \mathrm{C} / 75 / \mathrm{D} / 854 / 1999$.

Waldron, J. 2005. Torture and Positive Law: Jurisprudence for the White House. Columbia Law Review 106: 1681-1750.

- 2007. Dignity and Rank. European Journal of Sociology 48: 201-23.

- 2008. The Concept and the Rule of Law. Georgia Law Review 43: 1-61.

- 2011. Dignity, Rights, and Responsibilities. Arizona State Law Journal 43: 1107-36.

- 2012a. How Law Protects Dignity. The Cambridge Law Journal 71: 200-22. 
- 2012b. Dignity, Rank, and Rights. Oxford: Oxford University Press.

- 2013. 'Is Dignity the Foundation of Human Rights?' NYU School of Law, Public Law Research Paper 12-73, available at http://ssrn.com/abstract=2196074 last accessed 10/11/17.

Webster, E. 2016. Interpretation of the Prohibition of Torture: Making Sense of 'Dignity' Talk. Human Rights Review 17: 371-90.

Weinrib, J. 2016. Dimensions of Dignity: The Theory and Practice of Modern Constitutional Law, Cambridge: Cambridge University Press.

\section{Acknowledgments}

Versions of this paper were presented at Utrecht University, Strathclyde University, and the University of Leicester. My thanks for questions and suggestions received at those events and for detailed comments by Dr Clark Hobson and reviewers at Ratio Juris. Any remaining faults are mine alone. 